$\begin{array}{rrr}\text { 建設省土木研究所 } & \text { 青山憲明 } & \text { 竹内辰典 } \\ \text { 挂間組技術研究所 } & \text { ○泰永裕之 } & \text { 加藤俊昭 }\end{array}$

\title{
1.まえがき
}

ポリマーグリッド、不織布などのジオテキスタイルを盛土内に水平に数設することにより、のり面勾 配を急にすることができ、また降雨や地票に対して強い盛土を築造することができるという禣強土工法 が注目を集め、また多用されるようになってきた。しかし、その補強メカニズムには未解明の部分が多 く、現在用いられている設計法の多くは函限つり合い法に基づくものであり、極限状熊のモーメントあ るいは土圧のつり合いのみを対象としている。ところが、ジオテキスタイル補強盛土は、盛土上に椿造 物ができる場合などを考えると、最終的な支持力だけでなく、变形についても考虑する必要がある。ま た、ジオテキスタイルが引張り補強材であると考えるなら、変形状況が重要な意味を持つこととなる。 今回は小型土槽内にジオテキスタイルを一屏数いた補強盛土を作り、上部より载荷するという実鈋を 行い、ジオテキスタイルの種類、長さが、その変形、支持力に及ぼす影做を調べ、また、分割法による 安定計算を適用し、その妥当性の検討を行った。

\section{2. 実弱树要}

\section{1 実験材料}

(1) ジオテキスタイル

今回の実験では樹脂ネットを用いることとした。表-1に今回 使用したネットの物性を示す。なお、BとDはそれぞれAとC の目合いを $2 \times 2$ 倍としたものである。

表-1 快用ジオテキスタイル

\begin{tabular}{|c|c|c|c|c|c|c|c|}
\hline \multirow[t]{2}{*}{ G.T. } & \multicolumn{2}{|c|}{ 目合心 } & \multicolumn{2}{|c|}{$\underset{\left(h_{s} f / m\right)}{\text { 개 }}$} & \multirow[t]{2}{*}{ ") } & \multirow[t]{2}{*}{ 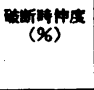 } & \multirow[t]{2}{*}{ 同 } \\
\hline & $9 \bar{F}$ & בנב & $9 \bar{i}$ & 33 & & & \\
\hline A & \begin{tabular}{|l|l}
10 & 1
\end{tabular} & 10 & 800 & 800 & 2.1 & 400 & LDPE \\
\hline$B$ & $\begin{array}{lll}20 & 2\end{array}$ & 20 & 400 & 400 & 2.1 & 400 & LDPE \\
\hline c & \begin{tabular}{|l|l|l}
10 & 1
\end{tabular} & 10 & 160 & 160 & 1.5 & 500 & LOPE \\
\hline D & \begin{tabular}{l|l}
20 & 2
\end{tabular} & 20 & 80 & 80 & 1.5 & 500 & LDPE \\
\hline
\end{tabular}

（2）地盤材料

気乾状態の豊浦標準砂（此重2.64、含水比0.5\%) を高さ20cmから一様に自由落下させ盛土地盤を作製 した。湿洞密度は $1.39 \mathrm{~g} / \mathrm{cm}^{3}$ であり、この状熊での 強度定数は三軸圧縮試験より、粘着力 $0.0 \mathrm{~kg} / \mathrm{cm}^{2}$ 、 内部摩擦角40.0度であった。

\section{2 実験装置}

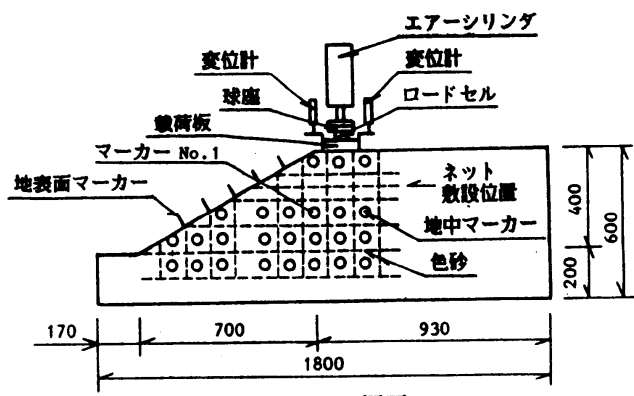

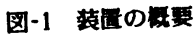

実験装圆は、土槽、载荷装置、計测装置（変位計、ロードセル、ひずみゲージ）よりなる。 土槽は内法が $1800(W) \times 600(B) \times 800(H) m m$ ののである。正面の両側板には厚さ25mmの透明なアクリ ル板を設置し、内部の挙動が钼察できる棈造となっている。测定項目は、载荷板の沈下、のり面の変位、 盛土内变位、載荷荷重、ジオデキスタイルに生じるひずみである。装置の概要を図-1に示す。 
2.3 実凂方法

表-2 実娩ケース

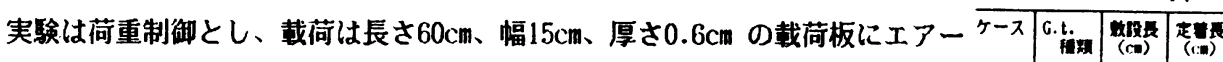
シリンダを用いて圧力をかけることにより行った。なお、各荷重段階における荷

重の制御は、载荷板とエアーシリンダの間にロードセルを介し、これをモニタリ ングしながら行った。

実駼は、まず無補強の場合について行い、この時発生したすべり面を潜在すべ

り面として、以後の実駼におけるジオテキスタイル数設長を決定した。なお、潜 在すべり面から盛土奥行き方向のジオテキスタイル数設長を定着長とし、定着長

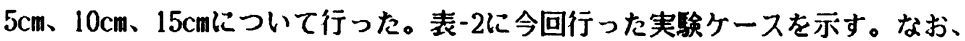
ジオテキスタイル散設梁度は15cmとし、全ケース一定とした。

\begin{tabular}{|c|c|c|c|}
\hline & Fin & $(\mathrm{cus})$ & (iii) \\
\hline 1 & 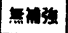 & - & - \\
\hline 2 & A & 45 & 5 \\
\hline 3 & A & 50 & 10 \\
\hline 4 & A & 55 & 15 \\
\hline 5 & B & 45 & 5 \\
\hline 6 & B & 50 & 10 \\
\hline 7 & B & 55 & 15 \\
\hline 8 & c & 45 & 5 \\
\hline 9 & $c$ & 50 & 10 \\
\hline 10 & C & 55 & 15 \\
\hline 11 & D & 45 & 5 \\
\hline 12 & D & 50 & 10 \\
\hline 13 & D & 55 & 15 \\
\hline
\end{tabular}

\section{3. 実駼結果}

\section{1 すべり面の形状}

図-2に無補強の場合の変形状況を示す。このケースでは载荷板の 端部（のり面反対側）からほぼのり尻部に達するすべり面が形成さ れている。このすべり面（以後、潜在ずべり面と言う）は、円弧と 直線からなる複合すべり面であると言えよう。

表-3にケース 2〜13の最終段階の変形状況を示す。

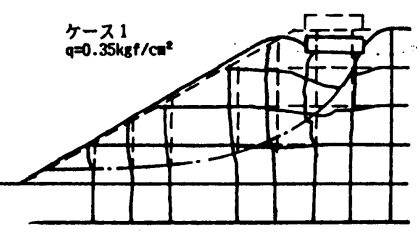

图-2焦補強の㙋合の变形状况

表-3 交形状呮

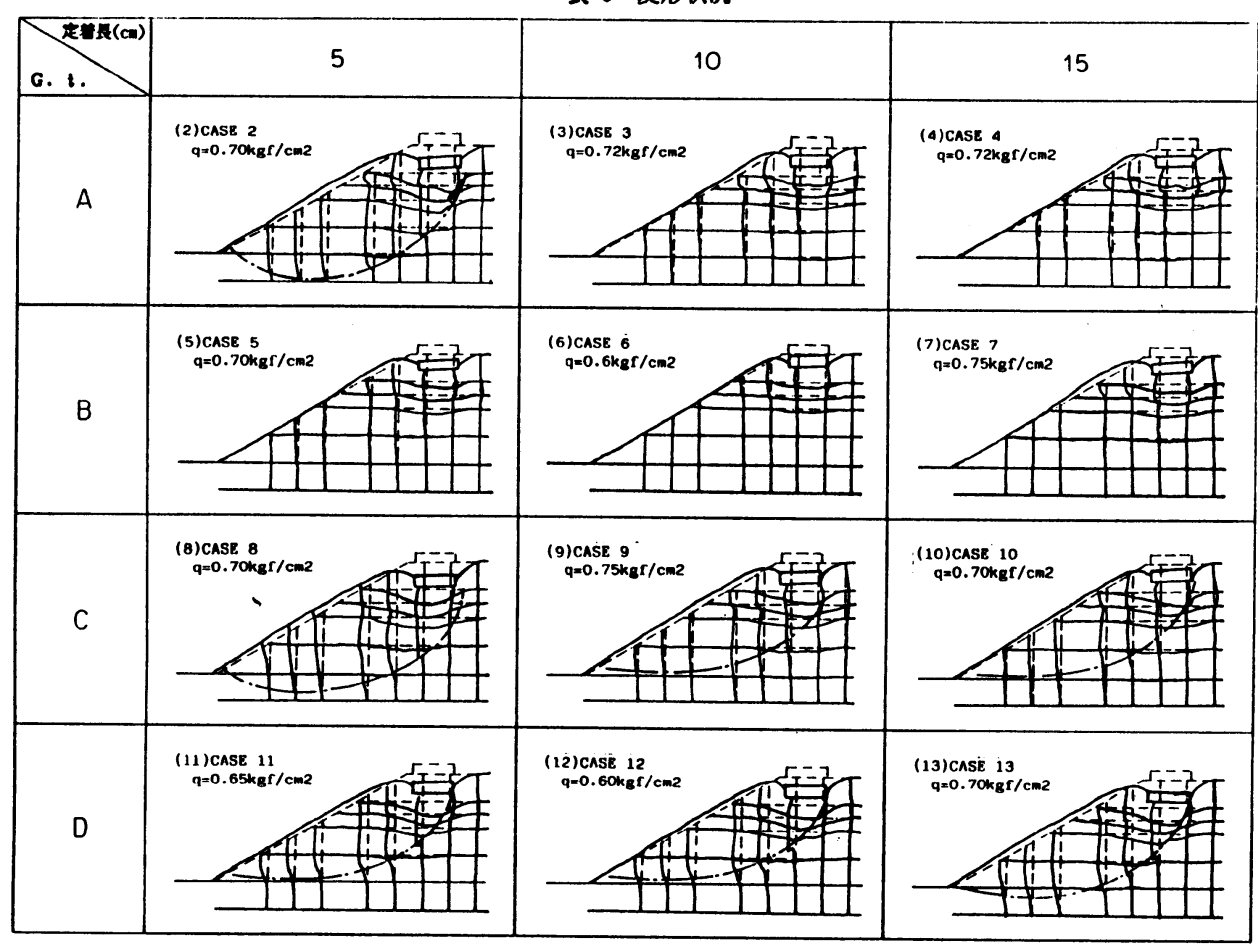

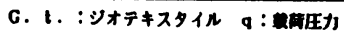


定着長 $5 \mathrm{~cm}$ の場合には、AとCではジオテキスタイル末端を通る、潜在すべり面より大きなすべり面 が形成されている。Bではジオテキスタイル上部の砣のはらみ出しが起こった以外は、明確なすべり面 は形成されなかった。Dでは潜在すべり面とほぼ同一のすべり面が形成されている。

定着長10cmの場合には、Aと Bではジオテキスタイル上部の砂のはらみ出し以外には明確なすべり面

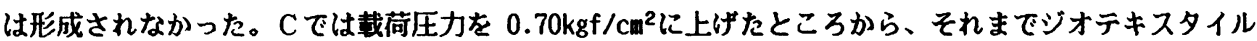
上部の砂のはらみ出ししか起こっていなかったのが、ジオテキスタイル下部の砂にも潜在すべり面の位 置にすべり面が形成されだした。Dでは潜在すべり面とほぼ同一のすべり面が形成された。

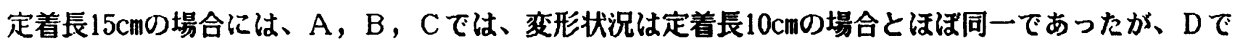
は、定着長10cmの場合に形成されたすべり面より若干大きなすべり面が形成された。

なお、実験終了後、ジオテキスタイルを取り出したところ、Dはいずれの定着長の場合も潜在すべり 面の位置で伸びが観察された。

\section{2 載荷板の沈下量}

図-3に载荷圧力と载荷板沈下量の関係を示す。各ケースとも無補強の場合に比べ、同一圧力時におけ る沈下量は少なくなっており、載荷に伴う沈下について補強効果はあると言えよう。

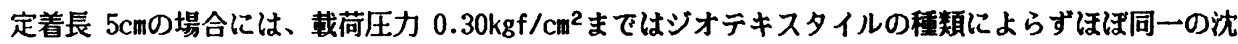
下傾向を示す。その後A、C、Dはほぼ同一の沈下傾向を示すが、Bの場合の沈下の進行だけが、他の ジオテキスタイルの場合に比べて遅くなっている。

定着長 $10 \mathrm{~cm} 、 15 \mathrm{~cm}$ 場合には、载荷圧力 $0.30 \mathrm{kgf} / \mathrm{cm}^{2}$ までは、ジオテキスタイルによらずほぼ同一の 沈下傾向を示す。その後、Bの沈下の進行が他のジオテキスタイルの場合に比べて蓬くなっている。A、 C、Dについては、载荷圧力 $0.50 \mathrm{kgf} / \mathrm{cm}^{2}$ まではほぼ同一の沈下傾向を示し、その後Dの沈下の進行か A、Cに比べて速くなっている。

各ジオテキスタイル別で比较した場合、A、Cでは载荷圧力 $0.40 \mathrm{~kg} / \mathrm{cm}$ ままでは定着長によらずほぼ 同一のカーブを示し、それ以後、定着長 $5 \mathrm{~cm}$ 場合だけ他の定着長に比べて、沈下の進行が速くなって いる。B、Dでは定着長によらず、ほぼ同一の沈下傾向を示している。

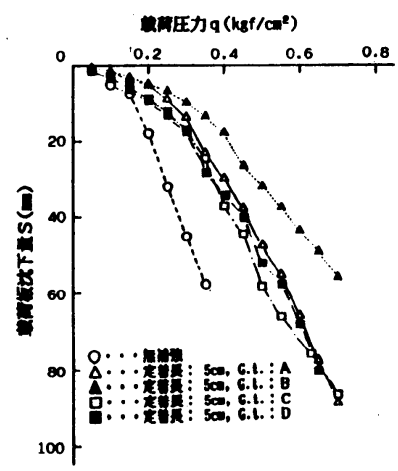

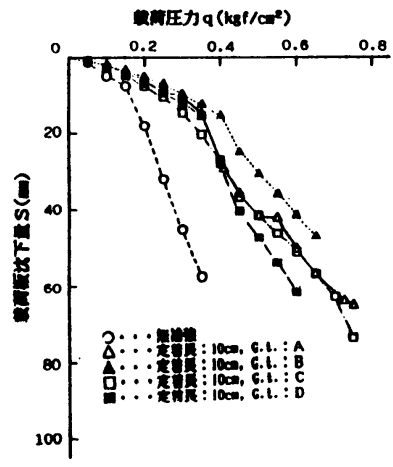

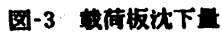

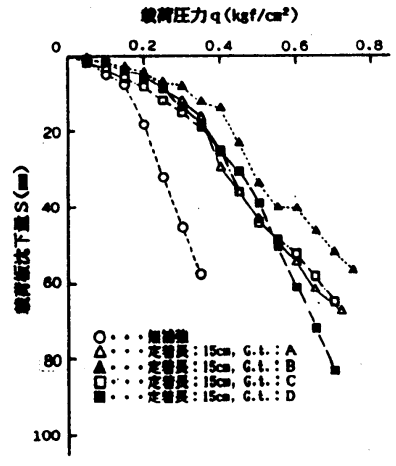


表-4に各ケースの降伏載荷圧力 $q y_{1} 、 15 \mathrm{~mm}$ 沈下時 表-4 藏板视下量 の载荷圧力q、载荷圧力 $0.35,0.60 \mathrm{kgf} / \mathrm{cm}^{2}$ 時の沈下 量Sを示す。なお(4)の無補強の場合の沈下量は载荷 圧力と载荷板沈下量の関係が降伏後は直線関係にあ るとして载荷圧力 $0.60 \mathrm{kgf} / \mathrm{cm}^{2}$ の場合の沈下重を推 定した值である。

\section{3 地中变位量}

地中変位量として、図-1に示すNo.1マーカーの変 位量に着目した。図-4に載荷圧力と地中变位量の関 係を示す。なお、水平変位量は盛土斜面侧を、鉛直 変位量は鉛直下向きを正とした。

\begin{tabular}{|c|c|c|c|c|}
\hline ケース & 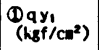 & $\underset{S=15=1}{q}\left(k s f / c^{2}\right)$ & $\underset{q=0.35 \mathrm{kgf}^{\prime} / \mathrm{cm}^{2} \mathrm{~m}}{\operatorname{Sin}}$ & (4) $S\left(\infty=0.60 \mathrm{kgf} / \mathrm{cm}^{2} \mathrm{th}\right.$ \\
\hline 1 & 0.17 & 0.19 & 57.5 & $(120.0)$ \\
\hline 2 & 0.30 & 0.31 & 23.2 & 65.7 \\
\hline 3 & 0.35 & 0.35 & 14.8 & 50.1 \\
\hline 1 & 0.35 & 0.34 & 16.3 & 55.4 \\
\hline 5 & 0.40 & 0.37 & 13.5 & 43.4 \\
\hline 6 & 0.40 & 0.39 & 12.4 & 41.6 \\
\hline 7 & 0.40 & 0.41 & 12.0 & 40.0 \\
\hline 8 & 0.30 & 0.28 & 24.7 & 73.0 \\
\hline 9 & 0.40 & 0.30 & 20.0 & 51.2 \\
\hline 10 & 0.40 & 0.30 & 19.3 & 52.1 \\
\hline 11 & 0.30 & 0.27 & 28.7 & 68.0 \\
\hline 12 & 0.35 & 0.35 & 15.2 & 61.5 \\
\hline 13 & 0.35 & 0.32 & 18.0 & 01.2 \\
\hline
\end{tabular}

定着長 $5 \mathrm{~cm}$ の場合には、A、C、Dは水平変位、鉛直変位ともほぼ同一の傾向を示す。Bは他のジオ テキスタイルに比べて、水平变位、垂直变位とも変位の進行が革い。 定着長10cmの場合には、A、B

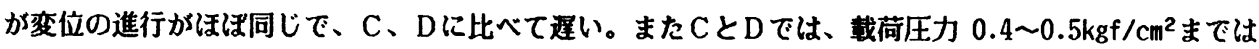
ほほ同一であるが、それ以後、Dの変位の進行が速くなっている。

各ジオテキスタイル別で比较した場合、A、Cについては、定着長 $5 \mathrm{~cm} の$ 場合が最も水平変位の進行 が速く、定着長 $10 \mathrm{~cm} 、 15 \mathrm{~cm}$ の間に明確な差はない。B、Dでは、定着長による差は若干認められるもの のさほど顥著ではない。

表-5に各ケースの水平変位から求めた降状载荷圧力 $\mathrm{q}_{2} 、 5 \mathrm{~mm}, 10 \mathrm{~mm}$ 水平変位時の载荷圧力 $\mathrm{q}$ 、载荷圧 力0 $35,0.60 \mathrm{kgf} / \mathrm{cm}^{2}$ 時の水平変位量 $\delta$ を示す。なお(4)の無補強の場合の水平変位量は、载荷圧力と水平 変位量の関係か降伏後は直線関係にあるとして载荷圧力 $0.60 \mathrm{kgf} / \mathrm{cm}^{2}$ の場合の水平変位量を推定した値 である。

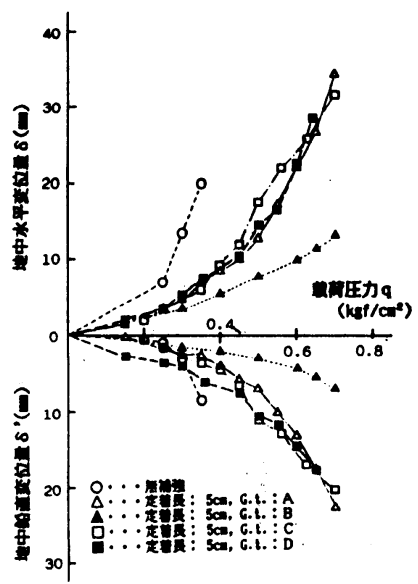

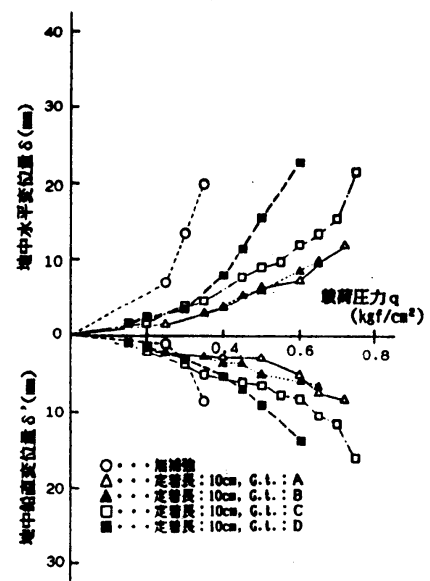

图-4 地中紊位目 (No.1)

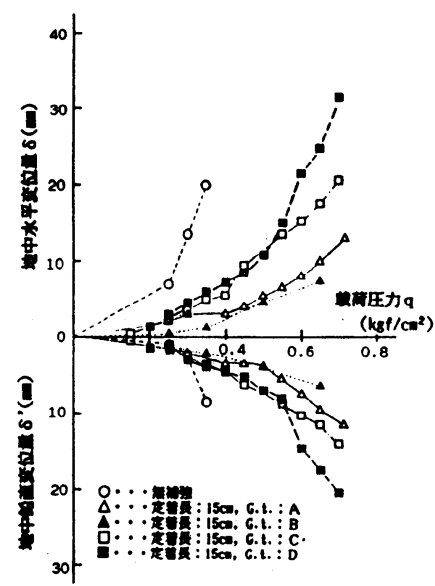

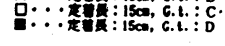




\section{4. 考察}

\section{1 補強効果}

今回行った実験から、ジオテキスタイル敨

設による補強効果を表-6に示す項目について、

無補強の場合に対する比で考えることとする。

これより、引張り強度ではAが一番大きい が、Bの方が補強効果、特に変形の抑制効果 があるという結果を得た。つまり、変形の抑 制効果は、ジオテキスタイルの引張り強度だ けでは判断できないということである。よっ てジオテキスタイル補強盛土では、盛土にせ ん断面が現れるまでの補強効 果は、そのせん断面で発揮さ れるジオテキスタイルの引張 り強度だけで評価できるむの ではなく、ジオテキスタイル と土との境界面での摩擦抵抗、 すなわち、ジオテキスタイル のヤング率、目合いの大きさ などか関与してくるものと思 われる。

\begin{tabular}{|c|c|c|c|c|c|c|c|c|c|c|c|}
\hline $3-2$ & $\begin{array}{l}\text { G.t. } \\
\text { Hot. }\end{array}$ & $\begin{array}{c}\text { 定期) } \\
(\mathrm{cm})\end{array}$ & ats $^{151}$ & $s=15$ & 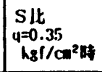 & 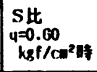 & $\begin{array}{l}q y_{2} \\
\mathbb{t}^{2}\end{array}$ & $\begin{array}{l}\text { qut } \\
\delta=5 \\
\text { mil }\end{array}$ & $\delta=10$ & $\begin{array}{l}\delta \text { 比 } \\
4=0.30 \\
\mathrm{~kg} / \mathrm{c} / \mathrm{cm}\end{array}$ & 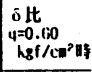 \\
\hline 2 & $\lambda$ & 5 & 1.76 & 1.10:3 & 0.10 & 0.55 & 2.25 & 1.55 & 1.07 & 0.35 & 0.10 \\
\hline 3 & $A$ & 10 & 2.00 & 1.84 & 0.26 & 0.42 & - & 2.30 & 2.44 & 0.15 & 0.13 \\
\hline 4 & A & 15 & 2.06 & 1.79 & 0.28 & 0.46 & - & 2.40 & 2.37 & 0.15 & 0.15 \\
\hline 5 & B & 5 & 2.35 & 1.95 & 0.23 & 0.36 & - & 1.90 & 2.22 & 0.20 & 0.18 \\
\hline B & B & 10 & 2.35 & 2.05 & 0.22 & 0.35 & - & 2.30 & 2.41 & 0.15 & 0.15 \\
\hline 7 & B & 15 & 2.35 & 2.16 & 0.21 & 0.33 & - & 2.00 & - & 0.09 & 0.11 \\
\hline 8 & C & 5 & 1.70 & 1.47 & 0.43 & 0.01 & 2.00 & 1.50 & 1.52 & 0.30 & 0.42 \\
\hline 9 & C & 10 & 2.35 & 1.58 & 0.35 & 0.43 & 3.50 & 1.85 & 2.07 & 0.23 & 0.22 \\
\hline 10 & C & 15 & 2.35 & 1.58 & 0.34 & 0.43 & 3.50 & 1.75 & 1.74 & 0.25 & 0.28 \\
\hline 11 & I) & 5 & 1.70 & 1.42 & 0.50 & 0.57 & 2.00 & 1.45 & 1.56 & 0.39 & 0.41 \\
\hline 12 & D & 10 & 2.06 & 1.84 & 0.26 & 0.52 & 2.00 & 1.00 & 1.59 & 0.30 & 0.41 \\
\hline 13 & D & 15 & 2.06 & 1.68 & 0.31 & 0.51 & 2.50 & 1.00 & 1.78 & 0.30 & 0.41 \\
\hline
\end{tabular}

表-5 地中水平变位量 (No.1)

\begin{tabular}{|c|c|c|c|c|c|}
\hline rース & $\underset{\left(\mathrm{hsf} / \mathrm{cm}^{2}\right)}{q \mathrm{~s}_{2}}$ & $\begin{array}{l}2 \mathrm{q}\left(\mathrm{hgf} / \mathrm{cm}^{2}\right) \\
\delta=5 \text { 而時 }\end{array}$ & $\begin{array}{c}3 \mathrm{q}\left(\mathrm{hgf} / \mathrm{cm}^{2}\right) \\
0=10 \text { 暗 }\end{array}$ & $\underset{q=0.35 h_{\mathrm{hf}} / \mathrm{cm}^{2}}{\mathrm{o}(m)}$ & $\begin{array}{l}3 \dot{j}(\mathrm{~m}) \\
y=0.60 \mathrm{hsf} / \mathrm{cm}^{2}\end{array}$ \\
\hline 1 & 0.20 & 0.20 & 0.27 & 20.0 & $(55.0)$ \\
\hline 2 & 0.15 & 0.31 & 0.45 & 7.0 & 22.0 \\
\hline 3 & - & 0.46 & 0.66 & 3.0 & 7.3 \\
\hline 4 & $\longrightarrow$ & 0.48 & 0.64 & 3.0 & 8.0 \\
\hline 5 & $\longrightarrow$ & 0.38 & 0.60 & 4.0 & 10.0 \\
\hline 6 & - & 0.16 & 0.65 & 3.0 & 8.5 \\
\hline 7 & - & 0.52 & - & 1.8 & 6.0 \\
\hline 8 & 0.40 & 0.30 & 0.41 & 6.0 & 22.3 \\
\hline 9 & 0.70 & 0.37 & 0.56 & 4.5 & 12.0 \\
\hline 10 & 0.70 & 0.35 & 0.47 & 5.0 & 15.2 \\
\hline 11 & 0.70 & 0.23 & 0.42 & 7.8 & 22.8 \\
\hline 12 & 0.40 & 0.32 & 0.43 & 6.0 & 22.8 \\
\hline 13 & 0.50 & 0.32 & 0.48 & 6.0 & 21.5 \\
\hline
\end{tabular}

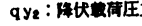

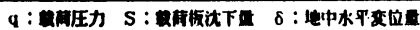

\section{2 分割法による安定計算}

ジオテキスタイル数設により、ジオテキスタイルの引 張り強さがすべりに対する抵抗力に付加されると考えて 求めた潜在すべり面に対する安全率と载荷圧力の関係を 図-5に示す。また、定着長 $5 \mathrm{~cm}$ の場合に形成されたジオ テキスタイル末端を通るすべり面に対する安全索と載荷 圧力の関係も示す。なお、図中の矢印は、今回の実験か ら得られた載荷圧力〜地中水平変位量より求めた降伏点 である。

これより、実験で得られた降伏点は安全率 $0.9 \sim 1.0$ の間にあり、ジオテキスタイルの引裂き破堙、ジオテキ

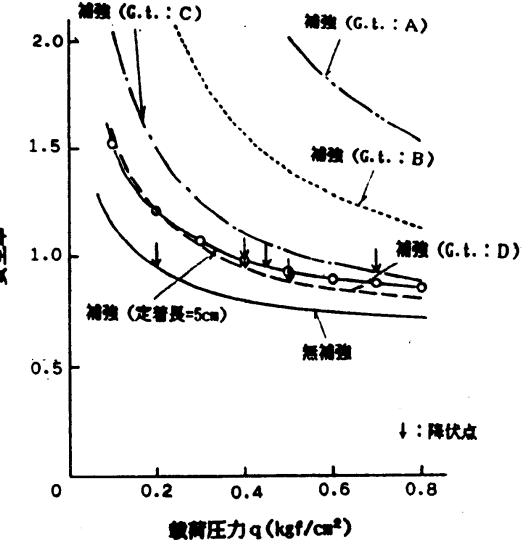

图-5 安全事 スタイル末端を通るすべり破壊の検討に対しては、分割法が十分適用できると言えよう。 
また、Aについては、ジオテキスタイル

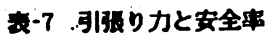

に発生したひずみを求めたので、これに引 張り試験から求めたヤング害をかけて、実

祭にジオテキスタイルに作用した引張りカ を求め、この引張り力を用いて安定計算を 行った。計算結果を表-7に示す。

これより、定着長 $10 \mathrm{~cm} 、 15 \mathrm{~cm}$ 場合につ

\begin{tabular}{|c|c|c|c|c|c|c|c|c|c|}
\hline \multirow{2}{*}{ 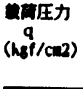 } & \multicolumn{3}{|c|}{ 实贯 $\mathrm{j} \mathrm{cm}$} & \multicolumn{3}{|c|}{ 走霄县10 cm } & \multicolumn{3}{|c|}{ 走粪甚 $15 \mathrm{~cm}$} \\
\hline & $\begin{array}{l}0+7 \\
(10-0)\end{array}$ & $\begin{array}{c}\text { 光势り力 } \\
(\mathrm{sf} / \mathrm{cm})\end{array}$ & 军全部 & $\begin{array}{l}\text { Urz } \\
\left(10^{-0}\right)\end{array}$ & 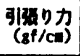 & 安全种 & $\begin{array}{l}\text { Uా゙ } \\
\left(10^{-6}\right)\end{array}$ & 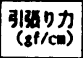 & 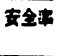 \\
\hline 0.10 & 343 & 147 & 1.23 & 456 & 195 & 1.26 & 433 & 185 & 1.25 \\
\hline 0.20 & 818 & 350 & 1.06 & 1261 & 540 & 1.12 & 324 & 398 & 1.07 \\
\hline 0.30 & 1545 & 662 & 1.01 & 2161 & 926 & 1.07 & 1588 & 680 & 1.01 \\
\hline 0.40 & 2221 & 951 & 0.98 & 3201 & 1371 & 1.08 & 2402 & 1029 & 0.99 \\
\hline 0.50 & 2838 & 1216 & 0.36 & 4211 & 1804 & 1.05 & 4022 & 1723 & 1.03 \\
\hline 0.60 & 3898 & 1670 & 0.96 & 5737 & 2457 & 1.07 & 6317 & 2706 & 1.10 \\
\hline 0.70 & 5279 & 2261 & 0.09 & 8865 & 3717 & 1.15 & 9130 & 3911 & 1.18 \\
\hline
\end{tabular}

いては、すべりに対する抵抗力の不足分をジオテキスタイルの引張り力が䒴っていると言えよう。定着 長 $5 \mathrm{~cm}$ 場合には、ジオテキスタイル末端を通るすべりが生じたため、十分な引張り力が発揮されてい ないと言えよう。

5.まとめ

今回の実弱より以下のことが亩えよう。

(1)゙オテキスタイルの引張り強度、散設長により、形成されるすべり面は異なる。

(2ジオテキスタイルの定着長にはある最適長さ（今回の実駼では $10 \mathrm{~cm}$ ）があり、それ以上とった場合で も補強効果はあまり変わらない。

(3)ジオテキスタイルの補強効果として、载荷に伴う変形の抑制を考えた場合、引張り強度だけでなく、

ジオテキスタイルのヤング臬、目合いの大きさなども重要な要素である。

(4)ジオテキスタイル補強盛土についてのジオテキスタイル引き裂き破填、ジオテキスタイル末端を通る すべり破溒に対する検討として、分割法が十分通用できる。

6.あとが

ジオテキスタイルを水平に数段した盛士の補強機棈に関する研究の第 1 段階として、今回、小型模型 盛土による載荷実験を行った。その結果、極限状態のつり合いに達するまでに盛土自体がかなり変形す ることから、その段階まで至る变形も考慮する必要があることが判明した。

しかし今回の実験は、爱詰めの秒筫盛土を対象としたものであり、ジオテキスタイルに十分なインタ 一ロッキング効果が生じていないことが予想される。今後は、多層敖段、密な盛土での蒲強効果につい ての実弱を引き统き行う予定である。

なお、本実鍳は建設省土木研究所との共同研究で実施したものである。

\section{参考文献}

1)建設省土木研究所他：昭和60年度ジオテキスタイルの土中での举動とその効果に関する研究報告费， pp. $104 \sim 113,1986$

2)泰永・加菲 : ジオテキスタイル数設による盛土斜面の補強効果に䦕する実弱的研究，第41回土木学会 年次学術請演会第 3 部, pp.869 870,1986. 


\author{
Yasuyuki Koga, Public Works Research Institute, Ministry oc Construction \\ Eiichi Taniguchi, \\ Yoshihiro Itoh, \\ Masahiko Sakaguchi, \\ Akira Nakanishi, \\ Takuya Sakemi, \\ Public Works Research Institute, Ministry of Construction \\ Public Works Research Institute, Ministry of Construction \\ Technical Research Institute, Taisei Corporation \\ Technical Research Institute, Taisei Corporation \\ Technical Research Institute, Taisei Corporation
}

This paper is concerning with small laboratory scale reinforced embankment subjected to horizontal sinusoidal seismic loading with a shaking table. In this test, we combined various parameters; the length of the reinforcing, the number of the reinforcing layers, the slope of the face and the sort of the reinforcing materials.

The result showed that the part of the reinforcing was acted as one block and the block resisted to the earth pressure like the gravity-type retaining wall.

Model Load Tests on Geotextile Reinforced Embankments

Noriaki Aoyama, Public Works Research Institute, Ministry of Construction, Tatsunori Takeuchi, Public Works Research Institute, Ministry of Construction Hiroyuki Yasunaga, Technical Research Institute, Hazama-Gumi Ltd. Toshiaki Kato, Technical Research Institute, Hazama-Gumi Ltd.

Most of design methods for geotextile reinforced embankments are based on only equilibrium of moment or earth pressure in the critical state, but deformation behaviour has to be taken into account.

This paper describes model load tests on geotextile reinforced embankments filled in a small box. And the influence of the kind and length of geotextile on bearing capacity and deformation behaviour was investigated. It was found that considerable deformation occures before it reaches the critical state, and that restraint of deformation can't be estimated only by ultimate tensile strength of geotextile. 